\title{
Z przemówień u trumny Kazimierza Twardowskiego
}

DOI: http://dx.doi.org/10.12775/RF.2018.003

Dnia 14 lutego 1938 odprowadzono we Lwowie na wieczny odpoczynek doczesne szczątki Kazimierza Twardowskiego. W czasie pogrzebu, który był potężną manifestacją żałobną nauki polskiej, przemawiali: przed domem żałoby J. M., Rektor Uniwersytetu J. K., dr E. Bulanda imieniem tegoż Uniwersytetu i prof. dr J. Hirschler imieniem Polskiej Akademii Umiejętności i Lwowskiego Towarzystwa Naukowego; przed starym gmachem uniwersyteckim Dziekan dr Z. Czerny imieniem Wydziałów Humanistycznego i Matematyczno-Przyrodniczego Uniwersytetu J. K.; nad otwartą mogiłą: prof. dr Z. Zawirski imieniem Uniwersytetu Jagiellońskiego i Krakowskiego Towarzystwa Filozoficznego; prof. dr St. Błachowski imieniem Uniwersytetu Poznańskiego i Towarzystwa Przyjaciół Nauk w Poznaniu; prof. M. Szczerbański imieniem Towarzystwa Nauczycieli Szkół Wyższych i Średnich; prof. dr R. Ingarden imieniem Polskiego Towarzystwa Filozoficznego; prof. dr T. Czeżowski imieniem Uniwersytetu S. B. w Wilnie i Wileńskiego Towarzystwa Filozoficznego; prof. dr T. Kotarbiński imieniem Uniwersytetu J. P. w Warszawie, Kasy im. Mianowskiego, Warszawskiego Towarzystwa Naukowego, Warszawskiego Towarzystwa Filozoficznego oraz imieniem uczniów.

\section{Zygmunt Czerny}

Gdy imieniem dwu bratnich Wydziałów Uniwersytetu Jana Kazimierza żegnamy Kazimierza Twardowskiego, Kolegę, Profesora, Dziekana, Rektora, Uczonego - wielką nauką niech będzie, że przywiedliśmy Go przed te czcigodne mury starego Uniwersytetu, w których przez z górą jedną trzecią wieku wykładał. Przywiedliśmy Go po to, by za Nim świadczyły. Przywiedliśmy Go tutaj my, Jego, który przez tyle lat chciał i miał prawo wodzić innych, ażeby Go w obliczu długoletniego 
Jego warsztatu pracy zmierzyć miarą sprawiedliwa, miarą pracy i obowiązku. I ocenimy Go tak, jakby On sam, najsurowszy sędzia, był obecny i dodać nie chciał niczego, a nie mógł niczego odrzucić.

$\mathrm{Tu}, \mathrm{w}$ tych starodawnych murach, od stuleci nasiąkłych atmosferą nauki, założył Kazimierz Twardowski pierwsze w Polsce naukowo prowadzone seminarium filozoficzne. Nie wśród wspaniałości nowoczesnego komfortu, ale niemal w piwnicznych murach pracował latami Mistrz i liczne, kolejne roczniki uczniów, w świetle wiecznie palących się lamp gazowych, rozświetlających suterenne mroki - w czym widzieliśmy głęboki symbol tego znicza myśli filozoficznej, który stąd świecić miał na całą Polskę. Nie żeby Polska przedtem nie miała filozofów ani też nie jakoby po Nim ich mieć już nie miała. Bo jest przecie losem i szczęściem nauki, że generacje uczonych pochodnię wiedzy z rąk do rąk sobie podając, do coraz wyższych celów dążyć muszą! Ale jest już dziś ustalone ponad wszelką wątpliwość, że w tych oto murach, jasny umysł i silna wola Człowieka, którego śmiertelne szczątki są przed nami - to Jego do dziś przez dziesiątki uczonych uwielbiane Seminarium Filozoficzne - ten "Ruch Filozoficzny" stworzony przezeń i redagowany aż na śmiertelnym łożu - to Polskie Towarzystwo Filozoficzne zbudowane i kierowane przezeń - nadały na kilkadziesiąt lat polskiej filozofii kierunek naukowy, którego nie byłoby, lub który nie byłby taki bez nieustającego wpływu Kazimierza Twardowskiego. To też dziś - rzecz wprost wyjątkowa w światowej historii szkół akademickich - na wszystkich uniwersytetach polskich pracują profesorowie, Jego uczniowie, którzy choć nie związani jednym systemem ani tą samą doktryną i ceniąc swą pełną naukową niezależność, mają przecie jedną wspólną postawę wobec nauki i wobec życia, tę właśnie, którą w nich śp. Profesor nauką swą i czynem swym wypracował, tę wspólnotę duchową wyrażającą się surową a prostą uczciwością myślenia, skrupulatnością pracy badawczej, bezwzględną ścisłością operowania narzędziem myśli.

Działalność śp. Profesora nie wyczerpywała się jednak w ciasnym, choć tak licznym kole adeptów filozofii. Swiadomie skupiał na swych wykładach nieprzeliczone rzesze studentów bez względu na ich specjalność, nawet $\mathrm{z}$ innych wydziałów - nie było przecie we Lwowie sali, która by starczyła. Skupiał ich koło swej katedry, aby niezmordowanie, a zarazem z najgłębszym zamiłowaniem, a nawet lubością apostolstwa nauczycielskiego wdrażać polską młodą inteligencję zawodową w schludność umysłowa, w ścisłość myślenia we wszystkich dziedzinach badania i pracy, by wyrabiać twardą świadomość obywatelskiej i narodowej odpowiedzialności za czyny.

Jako naukowiec zostawił po sobie dzieła nieprześcignionej jasności i ścisłości - o których inni mówić będą - a jako nauczyciel był jednym z najświetniejszych i najbardziej wpływowych wychowawców, jakimi Polska się wsławiła. $Z$ obu tych względów najwyższe polskie ciała 
i instytucje szczyciły się, zapraszając go do swego grona: był doktorem honorowym Uniwersytetów Poznańskiego i Warszawskiego, członkiem czynnym Polskiej Akademii Umiejętności i Towarzystwa Naukowego we Lwowie, członkiem honorowym Towarzystwa Przyjaciół Nauk w Poznaniu, Naukowej Kasy im. Mianowskiego w Warszawie i Polskiego Towarzystwa Filozoficznego we Lwowie, długoletnim prezesem Towarzystwa Nauczycieli Szkół Średnich i Wyższych.

Jako członek Rady Profesorów Wydziału Filozoficznego, a potem Humanistycznego, dwukrotny dziekan, trzykrotny rektor $\mathrm{w}$ tragicznych dla uniwersytetu lwowskiego latach Wielkiej Wojny, długoletni członek Senatu Akademickiego Uniwersytetu J. K., niezmordowany członek i przewodniczący licznych Komisyj Wydziałowych i Uniwersyteckich, miał przeważny autorytet niedoścignionego znawcy organizacji i administracji szkół akademickich i średnich. Przy budowaniu polskiego szkolnictwa po wojnie położył fundamentalne zasługi. Toteż, gdy po znojnym życiu, pracy i twórczości przeszedł w stan spoczynku, koledzy w uznaniu jego niespożytych zasług powołali go na profesora honorowego Wydziału Humanistycznego U. J. K., a Pan Prezydent Rzeczypospolitej zatwierdził te najwyższą godność i odznaczył Go Komandorią Polonia Restituta.

Gdy zaś odchodził z tego świata, On, który przez całe życie tak wysoko nosił godność nauki i posłannictwo nauczyciela akademickiego, On, który, będąc surowym dla innych, był nieubłaganym dla siebie, a tak serdecznym przywiązaniem otaczał warsztat pracy naukowej i młodzież akademicką pracującą - musiał czuć w ciszy serca światło wiecznej prawdy, stwierdzając, jak wśród nauczycieli akademickich i średnich, wśród badaczy naukowych wszelakich dziedzin wiedzy, liczne rzesze Jego wychowanków przekazują następnym pokoleniom Jego wskazania, błogosławiąc Jego pamięci i ścieląc Mu drogę w życie nieśmiertelne.

\section{Roman Ingarden}

Trzydzieści cztery lata minęły od chwili, gdy profesor Kazimierz Twardowski, po dziesięcioletniej już działalności na Uniwersytecie Lwowskim, założył Polskie Towarzystwo Filozoficzne - pierwsze na ziemiach polskich. Przez te 34 lata był jego dożywotnim prezesem, a od r. 1929 pierwszym i jedynym członkiem honorowym, a choć godności te świadczą o bezwzględnym uznaniu, jakim dla swych wielkich zasług cieszył się wśród członków Towarzystwa profesor Twardowski, to jednak nie mówią one wszystkiego. Nie mówią one, że Kazimierz Twardowski był nie tylko twórcą i kierownikiem Polskiego Towarzystwa Filozoficznego, ale i jego duszą. Był człowiekiem, dokoła którego wszystko się kupi- 
ło, który czuwał nad wszelkimi poczynaniami Towarzystwa, który był źródłem coraz to nowych jego przedsięwzięć i najskrupulatniejszym ich wykonawca, który wlewał w każdą pracę Towarzystwa całego swego ducha: swój światły rozum i swe serce gorące. Był tym, który nie tylko nadawał wysoki poziom naukowy pracom Towarzystwa, ale który zarazem nastrajał wszystkich jego członków na ton bezwzględnego oddania się dociekaniu prawdy i ton wysokiej etycznej odpowiedzialności za każde słowo, jakie tam wypowiadano. Licznymi odczytami własny$\mathrm{mi}$, stałym udziałem $\mathrm{w}$ dyskusjach naukowych, doborem prelegentów i tematów, a przede wszystkim mistrzowskim, wielce taktownym i bezstronnym, a zarazem energicznym kierowaniem obrad sprawił, że Polskie Towarzystwo Filozoficzne stało się dla filozofów lwowskich, a niebawem i polskich w ogóle, kuźnia, w której wykuwało się nowe idee i sprawne w ich opanowywaniu umysły. Więcej: Kazimierz Twardowski, pierwszy na ziemiach polskich sprawił siłą swej indywidualności, że Polskie Towarzystwo Filozoficzne stało się ośrodkiem w s półp ra cy filozoficznej, jakby wspólnym domem, ojczyzną filozofów polskich. Czuli się w nim u siebie, czuli się wszyscy w jego murach wielką rodziną. Zażarcie nieraz walczono w nim o idee i teorie i nie bano się nigdy z całą szczerością swych poglądów wypowiadać i krytykować cudzych teoryj, ale to nie naruszało w niczym tego poczucia wewnętrznego pokrewieństwa, jakie łączyło jego członków. Dzięki bowiem światłemu kierownictwu Profesora Twardowskiego, dzięki jego niezwykle jasnemu umysłowi, nauczono się od niego naw zajem się rozumieć, dzięki zaś jego etycznej postawie nauczono się siebie nawzajem szanować. To wzajemne rozumienie się - możliwe jedynie przy należytym wyjaśnieniu i opanowaniu środków wypowiedzenia - sprawiło, że wszyscy wiedzieli, iż wspólnie nad tymi samymi zagadnieniami pracują i te same trudności starają się rozwiązywać. Zrodziła się wspólnota duchowa takiej samej postawy badawczej i tego samego stylu myślenia, wspólnota współodpowiedzialności za tworzone teorie.

Tu na terenie Polskiego Towarzystwa Filozoficznego udało się Kazimierzowi Twardowskiemu dokonać tego, co się udaje tylko wyjątkowym uczonym: stworzyć - z niczego właściwie - jednolitą atmosferę naukową. Gdyby profesor Twardowski nie stworzył był Towarzystwa i nie działał przez lat z górą trzydzieści na jego terenie, gdyby zamiast tego był zamknął się w czterech ścianach i napisał jeszcze szereg dzieł, choćby najdonioślejszych, to nie wiadomo, czy dzieła te przy braku wszelkiej atmosfery, przy braku wzajemnego rozumienia się i współpracy, nie stałyby się nieme, czy nie bylibyśmy głusi na nie. Tylko dzięki działalności profesora Twardowskiego w Polskim Towarzystwie Filozoficznym filozofia stała się dla licznego grona młodych niegdyś uczonych sprawą żywą, czymś, co było formą i treścią ich o s o bi is te g o ż y ci a. I dlatego tylko mogło dojść do tego, że zaczęła się 
w Polsce nowa epoka badań filozoficznych i że styl myślowy tzw. szkoły lwowskiej w krótkim stosunkowo czasie opanował filozofię polską bez względu na osoby, szkoły i stanowiska. Tu, w Polskim Towarzystwie Filozoficznym - na setkach posiedzeń, w tysięcznych dyskusjach, w nieustannej walce nie tylko o idee, ale i o jasność myśli i odpowiedzialność sumienia naukowego - rodziła się współczesna filozofia polska. I jeżeli ta filozofia dziś istnieje, jeżeli wiemy, że teraz filozofowie europejscy bacznie nadsłuchują co się w filozofii polskiej dzieje, jeżeli mamy prawo nie wstydzić się, że pewna ważna dziedzina twórczości kulturalnej nie leży u nas odłogiem - to zasługą to jest Kazimierza Twardowskiego.

Toteż, gdy w tej chwili stoimy u trumny Kazimierza Twardowskiego, składam Mu kornie w imieniu Polskiego Towarzystwa Filozoficznego głęboką podziękę i hołd. Podziękę za trzydziestoletni trud i pieczę nad Towarzystwem, głęboką wdzięczność za serce, jakim je stale otaczał, hołd za najwyższej miary pracę obywatelską i naukową.

\section{Tadeusz Kotarbiński}

(Treść przemówienia "od uczniów” zanotował Autor 11 marca 1938 roku)

Mam pożegnać Zmarłego od uczniów. Trudne to zadanie, gdyż stosunek ich do Mistrza był uczuciowy, a uczucia - każdy ma osobiste. Zamiast wyrażać je wprost, snadniej by było dać obraz Nauczyciela w świetle uczuciowego spojrzenia. Jednak i tego nie uczynię teraz, ponieważ bardzo niedawno, z okazji siedemdziesięciu lat skończonych i nowego odznaczenia publicznego (nagrody miasta Łodzi) mówiło się o Nim tak właśnie przed odbiornikami rozgłośni polskich i pisało w czasopismach. Lepiej dziś pociągnąć dalej nić niedawnych wspomnień z ostatniego czasu.

Otóż, przed kilkoma miesiącami Profesor mówił do kogoś z naszego grona, że jest szczęśliwy. I podawał racje po temu. Powoływał się na swój wiek, piękny wiek, nie przewidywał tak długiego żywota. Doczekał niepodległej Polski i to dlań było źródłem trwałej radości. Pracował długie lata z zamiłowaniem jako profesor filozofii, a gdyby powtórnie miał wybierać zawód, wybrałby znowu ten, a nie inny. Osobliwie zaś cieszył się ze stosunku uczniów do Niego, stosunku zgoła wyjątkowego, stosunku, z którego niezwykłości zdawał sobie sprawę... Mówił to Człowiek prześladowany przez ciężką chorobę, ale nie znękany przez nia, przeciwnie, górujący nad cierpieniami opanowaniem ich wewnętrznym. Ta wypowiedź przypomina doprawdy list ostatni Epikura do Hermarcha. Nie jest to zbieżność przypadkowa, bo Profesor świadomie kształtował swoją postawę wedle wzoru dawnych starogreckich mistrzów etyki 
autonomicznej. Toteż w ostatnich latach życia własnym przykładem pouczał, jak znosić ból fizyczny i czynić zeń jedną więcej okazję do zwycięstwa skupionej woli.

Ilekroć traci się kogoś bliskiego, powstaje dręczące zagadnienie: jak obcować nadal z tym, kogo już nie ma i nie będzie i z kim już obcować nie można... Gdy odchodzi Nauczyciel, zadanie takie jest ułatwione. Można bowiem czynić dalej to, do czego zmierzał i zachęcał, i przez to świadome podążanie w Jego kierunku być $\mathrm{z}$ Nim jakoś nadal...

A coby uczynił Profesor w tej potrzebie, w której my się teraz znajdujemy? Po ukończonych obrzędach pogrzebowych pożegnałby szczątki przyjaciela, wróciłby do domu, zasiadł przy biurku, rozłożył papiery i zabrałby się do bieżącej, codziennej, a na dziś właśnie wyznaczonej, szarej z pozoru roboty, której nadawał doniosłość siłą uporczywą kierowniczego ducha. Szedł i prowadził ku mądrości, ku temu, co ukochane zarazem i zasługujące na miłość, jak mawiał Jego nauczyciel Brentano. Wcześniej na kartach „Fileba” ujął Plato dążność podobną w słowach

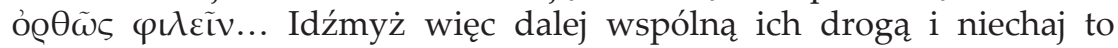
uprzytomnienie sobie miłości zasłużonej, ukochania, świadomego swej słuszności - będzie w obliczu odchodzącego Nauczyciela naszą intencją ostatnią. 